\title{
Consumers' Attitude towards Online Shopping in Janakpurdham
}

\author{
*Binod Shah, $\mathrm{PhD}^{1}$, and Uday Kishor Tiwari ${ }^{2}$ \\ ${ }^{1}$ Principal Author \\ Associate Professor \\ Faculty of management, R. R. M. Campus, Janakpurdham \\ Tribhuvan University, Nepal \\ ${ }^{2}$ Corresponding Author \\ Lecturer \\ FOM, Central Department of Management, Kirtipur \\ Tribhuvan University, Nepal \\ Email: * binod.sah@ rrmc.tu.edu.np \\ DOI: https://doi.org/10.3126/jom.v4i1.38660
}

\begin{abstract}
The paper aims to explore about the use of Internet that changes the way consumers purchase goods and services. The growing number of internet users in Nepal provides a bright prospect for online shopping. Recent research has shown an interest in investigating the factors that affect the attitude of consumers towards online shopping. The study is being carried out to identify and analyze the factors that affect consumers' attitude towards online shopping in Janakpurdham and to examine the factors that motivate consumers to shop online. In this study, quantitative research method has been used. Questionnaire method is used to collect the data. The study has been done by convenient sampling method. The main finding of this study is that among the four factors (convenience, website design/features, time saving and security) selected for this research, the most attractive and influencing factor for online shopping is convenience, followed by time saving the second and thirdly security. Results have also showed that the website design/features are also important for online shopping. The findings also indicate that time saving is the most important factor that motivate consumers to shop online, followed by easy to purchase second and thirdly variety at one shop. This study is useful to understand the online shopping behavior of consumers.
\end{abstract}


Keywords: consumers' attitude, e-commerce, internet shopping, internet users, online shopping behavior

\section{Introduction}

\section{Background of the Study}

Online or internet shopping is defined as purchasing goods and services from internet sellers at opposed to a shop or store. It is the act of purchasing goods or services over the internet. It is a form of electronic commerce (e-commerce) which allows customers to directly purchase goods or services from a seller over the internet using a web browser. Consumer buying behavior is the study of how individuals make decisions to spend their valuable resources (time, money, effort) on consumption related items (Schiffman \& Kanuk, 1991). Online shopping behavior consists of buying process of goods and services through internet. In a normal online buying process, consumers find a product of their interest by visiting the website of the seller directly or by searching among alternative vendors using a shopping search engine. Customers can shop online using a range of different computers and devices, including desktop computers, laptops, tablet computers and smart phones.

The invention of the internet has created a paradigm shift of the traditional way people used to shop. Due to revolution in telecommunication sector, internet has changed the way consumers shop and buy goods and services. Nowadays, internet shopping has been widely accepted as a way of purchasing goods and services. It has become a more popular means in the internet world (Bourlakis, Papagiannidis \& Fox, 2008). It also provides consumers more information and choices to compare product and price, more choice, convenience, easier to find anything online (Bulter \& Peppard, 1998). Online shopping has been shown to provide more satisfaction to modern consumers seeking convenience and speed (Yu \& Wu, 2007).

Internet World Stats (2020) stated that the number of people using the internet up to June 2020 exceeds 4,833 million. This number represents about $62 \%$ of total population of the world. In Nepal, the number of internet users has also risen exponentially. There were 16.19 million internet users in Nepal in May 2020. Internet penetration in Nepal stood at $55.60 \%$ in May 2020. This wide spread of internet has a revolutionary impact on person's life. Internet is changing the way consumers shop and buy goods and services and has rapidly evolved into a global phenomenon (Knupriya \& Kaur, 2016). 
There are many reasons why people shop online. Online shopping enables consumers to purchase products and services at any point of time and wherever they are located. It allows consumers to save money, effort and time when purchasing products. It offers consumers the ability to search and collect more information and with a high level of transparency and convenience. Consumers can find the same product at lower price by comparing different websites at the same time. They can find products which might be available only online from all over the world. Major reasons that impede consumers from online shopping may include unsecured payment, slow delivery, low quality product and fear of misusing personal information. Although there are many factors that influence a consumer to shop online, the researcher has selected four factors after reading literature in the field of consumers' attitude towards online shopping and these factors are as under:

\section{Convenience}

It is very time consuming to search products in a traditional store but through online shopping customers can easily search products without any delay. If it is easy to search the information through online, we say it is convenient for us. Convenience is a prime factor for consumers to shop online.

\section{Website Design/ Features}

One of the vital influencing factors of online shopping is website design. Website design, website reliability, website customer service and website security are the most important features which influence the perception of the consumers to shop online.

\section{Time Saving}

It is one of the important factors of online shopping. By shopping online, time can be saved and it can also reduce efforts of the customer. Time is saved with the help of online shopping during the purchasing of goods and the time required to go to the traditional store also gets reduced.

\section{Security}

Security is another dominant factor which affects consumers to shop online. Many internet users avoid online shopping because of credit card fraud, privacy factors, delivery risk and so on. Online shopping would fail if internet users feel on lacking a great degree of confidence. The most important reason not to shop online is that 
consumers are afraid to reveal personal credit card information to retailers or over the internet.

\section{Focus of the Study}

The main focus of this paper is to identify and analyze the factors that affect consumers' attitude towards online shopping. This paper also tries to assess the factors that motivate consumers to shop online in Janakpurdham.

\section{Statement of Problems}

The expansion of fast speed inexpensive internet facilities, the convenient modes of payments and user-friendly as well as interactive shopping apps are paving a pathway to unprecedented growth in e-commerce. The growth in the information technology sectors and the increasing number of young human resources in information technology sector directly created more opportunities for the growth of e-commerce in Nepal. Consumer's attitude towards online shopping refers to their psychological state in terms of making purchases over the internet (Dani, 2017). The attitude of consumers towards online shopping is known as the main factors that affect e-shopping potential. A large body of research is available on the online shopping in the world. Prior studies identified several factors that influence the consumers' attitude and behavior towards online shopping. These include convenience, time saving, website features, security etc. Therefore, it is needed to validate the findings of previous researches in the field of online consumer's attitude. This study tries to identify and analyze the factors that influence consumers to shop online. This study tries to seek the answers of following research questions:

- What factors affect consumers' attitude towards online shopping in Janakpurdham?

- What factors motivate consumers to shop online in Janakpurdham?

\section{Objectives of the study}

Following are the specific objectives of the study:

- To identify and analyze the factors that affect consumers' attitude towards online shopping in Janakpurdham.

- To examine the factors that motivate consumers to shop online in Janakpurdham. 


\section{Rationale of the Study}

Online shopping is an important business model in e-commerce. The present study would be of great importance to understand the factors that influence the consumers' attitude towards online shopping. This study can help the online sellers to enhance their knowledge and also increase their online marketing strategy effectiveness. If the online sellers want to persuade and retain online buyers, they need to know what the issues online buyers use to decide their online purchase. By understanding the factors that affect consumers' attitude towards online shopping, sellers can improve or create the effective marketing program for their customers. Understanding major motivations that lead customers to shop online, sellers should keep those issues in mind and try to satisfy customers whenever possible.

Understanding what make customers hesitate to shop online, sellers should find ways to reduce those negative aspects in order to gain more customers by building trustable and useful website and offering better online services. This study would pave the way for the growth of similar studies in the area of online shopping. This study will also increase the knowledge and research in the field of online shopping. It can be used as a basis for numerous scientific and innovative studies on consumers' attitude towards online shopping in coming days.

\section{Limitations of the Study}

The present study is subject to following limitations and constraints:

- The study area is limited to Janakpurdham only.

- The study is confined to the selected respondents from Janakpurdham. So, the results of this study cannot be generalized.

- The questionnaires may be misinterpreted by the respondents and therefore, the required information may not come out.

\section{Literature Review}

Goldsmith and Bridges (2000) in their study concluded that online shoppers are more worried about convenience, time-saving and selection whereas non-online shoppers are worried about security, privacy and on time delivery. Karim (2013) in his study concluded that the customers purchase products through online because they believe it is convenience to them and the term convenient includes elements such as time-saving, information availability, opening time, ease of use, websites navigation, 
less shopping stress, less expensive and shopping fun. Bhatt (2014) in his study focused on factors which online Indian buyers keep in mind while shopping online. This research found that information; perceived usefulness, perceived enjoyment and security/privacy are the dominant factors which influence consumer perceptions on online purchasing.

Kanchan, Kumar and Gupta (2015) in their article stated that online shopping is gaining popularity among people of young generation. Higher income groups and educated people are purchasing more via e-retailing websites. People have hesitations in doing online shopping due to security concerns. At the same time people are resistant to change because of technological complexity in making online purchase. Bhuyan (2016) revealed that online shopping is significantly affected by various factors like product information, variety of products offered, quality of products offered, price of products, offers and discount offered, advertising, safe online payment, speed of delivery, cash on delivery, convenience of shopping at home, time saving, website response speed, information of seller, website interface, after sales service and feedback.

Kothari \& Maindargi (2016) in their study analyzed the factors that motivates and affects customer's attitude towards online shopping in India. The study concluded that online shopping give customers the best alternative to save money and time. Companies Offers detail product information, easy mode of payment, facility of comparison of price and very important completely hassle-free shopping experience. Dani (2017) concluded that among the four factors selected for the study the most attractive and influencing factor for online shoppers in Kanyakumari District is Website Design/Feature, following convenience the second most influencing and thirdly time saving. Results have also showed that security is of important concern among online shoppers in India. The research has also found that there are some other factors which influence online shoppers including, less price, discount, feedback from previous customers and quality of product.

\section{Research Methods and Materials}

This study tries to identify and analyze the factors that affect the attitude of consumers towards online shopping in Nepal with special reference to Janakpurdham. The study focuses on analyzing the factors affecting the consumers' attitude towards online shopping based on factors like convenience, time saving, website features and security. This study also tries to examine the factors that motivate consumers to shop 
online. This section of the paper discusses the research design adopted for the study, types of data used in the study, sample size and data analysis tools.

\section{Research Design}

The nature of this study is a descriptive nature as well as survey research. Quantitative research method has been used in this study since the aim of this paper is to draw a picture on the topic as what are the factors that influence consumers to shop online.

\section{Types of Data}

Both primary and secondary data have been used. The primary data required for the study has been collected by conducting a survey through a well-structured questionnaire along with personal interview. Questionnaires were distributed both by online and by hand to the respondents and enough time was given to the respondents to fill the questionnaire in order to reduce sampling error. The design of questionnaire consists of two parts. The first part of the questionnaire is related to demographic characteristics and the second part of the questionnaire is related to the factors that affect the attitude of consumers towards online shopping. These factors are convenience, website design/features, time saving and security. There are four questions related to convenience, five questions related to website design, three questions related to time saving and three questions related to security. The secondary data required for the study has been obtained through published literature in books, journals, magazines, newspapers and websites.

\section{Population and Sample}

The target population of this study constitutes Nepalese online consumers residing in Janakpurdham. The study is mainly intended to identify and analyze the factors that affect the attitude of consumers towards online shopping in Janakpurdham and also to know the factors that motivate consumers to shop online. Keeping in view the limitation of time and resources, the researcher has decided to take the sample of 120 online shoppers from Janakpurdham. Samples were being selected as per convenience sampling method (as per their availability and willingness).

\section{Data Analysis Tools}

The data analysis tool used for this study is 5 Point Likert Scale ( $1=$ Strongly Disagree, 2 = Disagree, 3 = Neutral/ Uncertain, 4 = Agree, $5=$ Strongly Agree). This data analysis tool is used to evaluate empirical data. The Likert Scale is generally used 
for questionnaires and is mainly used in quantitative research. The beauty of Likert Scale is simplicity and easy to use. From the data collected from questionnaires, tables were generated, analyzed and interpreted with the help of excel sheets in computer. On the basis of findings on tabulated information and observations during data collection, conclusions were drawn.

\section{Research Framework}

Attitudes of consumers are perceived as dependent variable whereas convenience, website design/features, time saving and security are the independent variables that influence consumers' attitude towards online.

Independent Variables

Dependent Variable

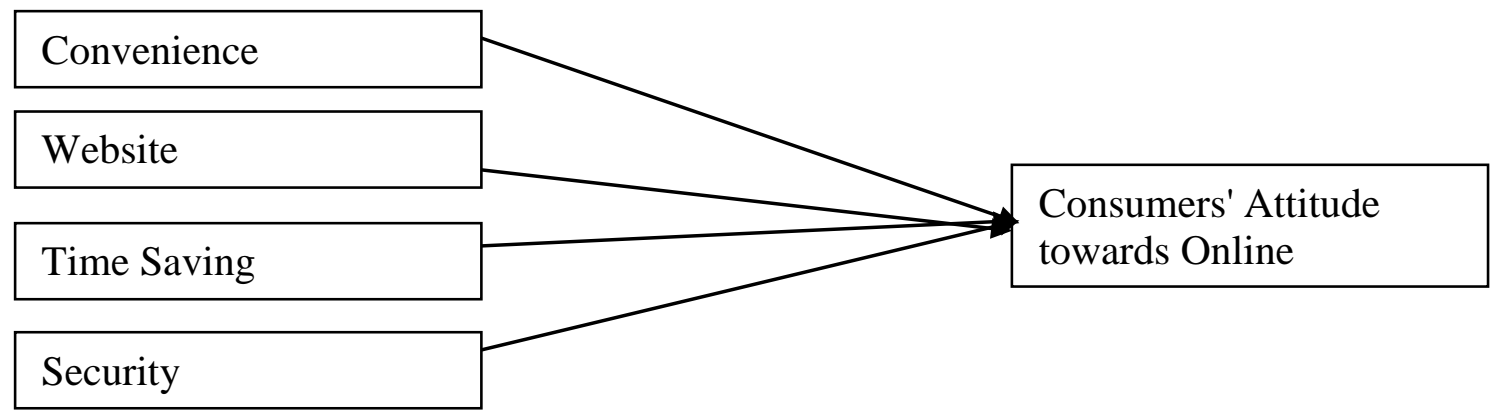

Notes. Sultan and Uddin (2011)

\section{Results and Discussion}

Attitudes of consumers towards online shopping are affected by so many factors. Here, the researcher has selected four factors, namely, convenience, website design/features, time saving and security that affect the attitude of consumers towards online shopping. Easy to purchase, time saving, variety at one shop, price and avoid hassles in shopping in store are the main factors that motivate consumers to shop online.

\section{Analysis of Respondents}

Personal and demographic information such as gender, age, occupation, income, education level and frequency of internet use are presented in Table 1: 


\section{Table 1}

Demographic Characteristics

\begin{tabular}{|c|c|c|}
\hline Variables & Frequency & Percentage \\
\hline \multicolumn{3}{|l|}{ Age } \\
\hline $16-25$ years & 21 & 17.50 \\
\hline 26 - 35 years & 75 & 62.50 \\
\hline 36 - 45 years & 18 & 15 \\
\hline Above 45 years & 6 & 5 \\
\hline Total & 120 & 100 \\
\hline \multicolumn{3}{|l|}{ Gender } \\
\hline Male & 75 & 62.50 \\
\hline Female & 45 & 37.50 \\
\hline Total & 120 & 100 \\
\hline \multicolumn{3}{|l|}{ Occupation } \\
\hline Students & 24 & 20 \\
\hline Professional & 36 & 30 \\
\hline Service & 27 & 22.50 \\
\hline Businessman & 12 & 10 \\
\hline Others & 21 & 17.50 \\
\hline Total & 120 & 100 \\
\hline \multicolumn{3}{|l|}{ Monthly Income } \\
\hline Below Rs 15,000 & 33 & 27.50 \\
\hline Rs. 15,000 - Rs. 25,000 & 48 & 40 \\
\hline Rs. 25,000 - Rs. 35,000 & 27 & 22.50 \\
\hline Above Rs. 35,000 & 12 & 10 \\
\hline
\end{tabular}




\begin{tabular}{lll}
\hline Total & 120 & 100 \\
Education Level & & \\
Secondary & 24 & 20 \\
Bachelor & 66 & 55 \\
Master and above & 30 & 25 \\
& 120 & 100 \\
Frequency of Internet Use & & \\
Less than 2 hours & 27 & 22.50 \\
$2-4$ hours & 45 & 37.50 \\
$4-6$ hours & 30 & 25 \\
More than 6 hours & 18 & 15 \\
\hline Total & 120 & 100 \\
\hline
\end{tabular}

Notes. Field survey, 2020.

Table 1 was drawn to understand the socioeconomic background of the respondents and it was found that out of 120 respondents, $62.5 \%$ are male and the rest $37.5 \%$ are female. Hence, it is concluded that majority of the respondents are male. It was found that that more than half $(62.50 \%)$ of respondents belonged to the age group of 26 - 35 years of age, while $17.50 \%$ belonged to the age group of $16-25$ years, $15 \%$ respondents belonged to the age group of 36-45 years of age and rest 5\% respondents were more than 45 years of age. The distribution of age group helps to understand the nature, structure, life-style and ultimately the buying behavior of respondents.

From Table 1, it was observed that out of 120 respondents, $20 \%$ are students; $30 \%$ of the respondents are professional; $22.50 \%$ are service holders; $10 \%$ are businessmen and rest are others. It is found that out of 120 respondents, $27.5 \%$ of respondents were having less than monthly income of Rs 15,$000 ; 40 \%$ of respondents were in monthly income group of Rs 15,000 - Rs 25,$000 ; 22.50 \%$ of respondents were in income group of Rs. 25,000 - Rs. 35,000 and $10 \%$ of respondents were in income group of greater than Rs. 35,000.

The researcher has categorized education level in three categories i.e. secondary, bachelor and master \& above. It is observed that out of total 120 
respondents, $20 \%$ of respondents were having secondary school level; $55 \%$ of respondents were having bachelor and $25 \%$ of respondents were having master and above. It was observed that $22.50 \%$ of respondents were using internet less than two hours per day, $37.5 \%$ of respondents were using internet $2-4$ hours daily; $25 \%$ of respondents were using internet $4-6$ hours per day and $15 \%$ of respondents were using internet more than 6 hours per day.

\section{Analysis of Four Factors}

For every individual item, mean was calculated and then finally the total mean of every dimension was calculated in order to know the most important factor which effects consumer buying through Online. Convenience factor carries four items; website design/features factor carries five items and time saving as well as security factor carries three items.

\section{Table 2}

Convenience

\begin{tabular}{lll}
\hline Items & Total Weight & Mean \\
\hline Convenience- Item 1 & 379 & 3.158 \\
Convenience- Item 2 & 432 & 3.600 \\
Convenience- Item 3 & 518 & 4.317 \\
Convenience- Item 4 & 436 & 3.633 \\
\hline Average mean & - & 3.677 \\
\hline
\end{tabular}

Notes. Field survey, 2020 and calculated data.

From Table 2, it was found that first item (I get on time delivery by shopping online.) has a mean of 3.158 which shows online shoppers get on time delivery by shopping online. The second item (Detail information is available while shopping online.) has a mean of 3.60 which shows a positive agreement towards the statement. Third item (I can buy the products anytime 24 hours a day while shopping online.) has a mean of 4.317 which shows strong positive agreement towards the statement. Fourth item (It is easy to choose and make comparison with other products while shopping online.) has a mean of 3.633 which shows a positive agreement with the statement. 
Table 3

Website Design/ Features

\begin{tabular}{lll}
\hline Items & Total Weight & Mean \\
\hline Website design - Item 1 & 408 & 3.40 \\
Website design - Item 2 & 325 & 2.708 \\
Website design - Item 3 & 339 & 2.825 \\
Website design - Item 4 & 311 & 2.592 \\
Website design - Item 5 & 319 & 2.658 \\
\hline Average mean & - & 2.837 \\
\hline
\end{tabular}

Notes. Field survey, 2020 and calculated data.

From Table 3, it was found that the first item (I prefer to buy from website that provides me with quality of information.) has a mean of 3.40 which shows the positive agreement with the statement. The second item (I believe that familiarity with the website before making actual purchase reduce the risk of shopping online.), third item (The website layout helps me in searching and selecting the right product while shopping online.), fourth item (While shopping online, I prefer to purchase from a website that provides safety and ease of navigation and order.) and fifth item (The website design helps me in searching the products easily.) have means of 2.708, 2.825, 2.592 and 2.658 respectively. It shows the respondents' disagreement towards the statements. The average mean for website design/features is less than 3 which shows that online shoppers have website issues while shopping online.

Table 4

Time Saving

\begin{tabular}{lll}
\hline Items & Total Weight & Mean \\
\hline Time saving - Item 1 & 409 & 3.408 \\
Time saving - Item 2 & 390 & 3.250 \\
Time saving - Item 3 & 351 & 2.925 \\
\hline
\end{tabular}




\begin{tabular}{|c|c|c|}
\hline Average mean & - & 3.194 \\
\hline \multicolumn{3}{|c|}{ Notes. Field survey, 2020 and calculated data } \\
\hline \multicolumn{3}{|c|}{$\begin{array}{l}\text { From Table 4, it was found that the first item (Online shopping takes less time } \\
\text { to purchase.) and second item (Online shopping doesn't waste time.) have means of } \\
3.408 \text { and } 3.250 \text { respectively. It shows the positive agreement of respondents towards } \\
\text { the statements. The third item (I feel that it takes less time in evaluating and selecting a } \\
\text { product while shopping online.) has a mean of } 2.925 \text { which shows that product } \\
\text { evaluation takes less time but not so much less. }\end{array}$} \\
\hline \multicolumn{3}{|l|}{ Table 5} \\
\hline \multicolumn{3}{|l|}{ Security Analysis } \\
\hline Items & Total Weight & Mean \\
\hline Security - Item 1 & 332 & 2.767 \\
\hline Security - Item 2 & 357 & 2.975 \\
\hline Security - Item 3 & 417 & 3.475 \\
\hline Overall mean & - & 3.072 \\
\hline
\end{tabular}

Notes. Field survey, 2020 and calculated data

From Table 5, it was revealed that the first item (I feel safe and secure while shopping online.) and second item (Online Shopping protects my security.) have a mean less than 3 which shows that online shoppers have security concerns while shopping online. The third item (I like to shop online from a trustworthy website.) has a mean of 3.475 which shows positive agreement towards the statement.

Table 6

Comparative Analysis of Four Factors

\begin{tabular}{lll}
\hline Variables & Average Mean & Rank \\
\hline Convenience & 3.677 & I \\
Website design/features & 2.837 & IV \\
Time saving & 3.194 & II \\
Security & 3.072 & III \\
\hline
\end{tabular}

Notes. Field survey, 2020 and calculated data. 
From Table 6, it was found that the average mean of convenience factor is 3.677 which is the highest score. It indicates that convenience is the most important factor that affects the attitude of consumers towards online shopping. Time saving has the second highest average mean (3.194) which shows that time saving is the second most important factor that affect the attitude of consumers towards online shopping. The average mean of security is 3.072 which show that security is also important factor for online shoppers while online shopping. The average mean of website design/features is 2.837 which shows online shoppers have some issues regarding website of online sellers.

\section{Analysis of Reasons to Shop Online}

Table 7

Reasons for Purchasing Online

\begin{tabular}{lll}
\hline Variables & Frequency & Percentage \\
\hline Easy to purchase & 27 & 22.50 \\
Time saving & 33 & 27.50 \\
Variety at one shop & 24 & 20.00 \\
Price & 21 & 17.50 \\
Avoids hassles in shopping in store & 9 & 7.50 \\
Other reasons & 6 & 5.00 \\
\hline Total & 120 & 100 \\
\hline
\end{tabular}

Notes. Field survey, 2020.

Table 7 reveals the reasons mentioned by the respondents to shop online. Out of 120 respondents, $22.5 \%$ of respondents opted for easy to purchase; $27.50 \%$ of respondents opted for time saving; $20 \%$ of respondents opted for variety at one shop; $17.50 \%$ of respondents opted for price, $7.50 \%$ of respondents opted for avoids hassles in shopping in store and remaining $5 \%$ of respondents opted for other reasons.. It was observed that major motive behind online shopping is time saving, followed by easy to purchase and variety at one shop. Other major motivations that lead consumers to shop online are price and avoid hassles in shopping in store.

\section{Major Findings}


On the basis of above discussion and tabulated information, the major findings of the study are summarized as under:

- Majority of consumers (80\%) having less than 35 years are keen to shop online.

- More than half $(62.5 \%)$ of the respondents are male.

- Professionals and service holders prefer to shop online than businessman, students and others.

- Generally, the consumers having bachelor degree and above prefer to shop online.

- Majority of respondents were using internet for two to six hours daily.

- The most influencing and attractive factor among four factors is convenience, followed by time saving that is second most important factor influencing the attitude of online consumers while online shopping. Security and website design/features are also important factors that affect the attitude of consumers towards online shopping.

- The major motive behind online shopping is time saving, followed by easy to purchase and variety at one shop. Other major motivations that lead consumers to shop online are price and avoid hassles in shopping in store.

\section{Conclusion}

Online shopping is becoming more popular day by day with the increase in the internet users in the world due to easy to purchase, availability of products and services 24 hours a day, variety of products at one shop and saving in time. Understanding the attitude of consumers towards online shopping has become challenges for online sellers. This paper has examined and analyzed the factors that affect the attitude of consumers towards online shopping. This study also focused on the factors that motivate consumers to shop online. The finding indicated that young consumers are keen to shop online. Professionals and service holders prefer to shop online than businessman, students and others. Consumers having bachelor degree and above prefer for online shopping. The finding indicated that among four factors selected for this research, the most influencing factor that affects the attitude of consumers towards online shopping is convenience, followed by time saving second and thirdly security. Website design/features is also important factor for online shopping. The study also revealed that the main reason for shopping online is time saving, followed by easy to purchase second and thirdly variety at one shop. Other major motivations that lead 
consumers to shop online are price and avoid hassles in shopping in store. By understanding the factors that affect the attitude of consumers towards online shopping and knowing the factors that motivate consumers to shop online; online sellers can gain the competitive advantage.

\section{References}

Bhatt, P. A. (2014). Consumer attitude towards online shopping in selected regions of Gujarat. Journal of Marketing Management, 2(2), 29-56.

Bhuyan, S. (2016). Factors influencing buying decision of online shoppers in Pune City. International Journal of Advance Engineering and Research Development, 3(11), 111-122.

Bourlakis, M.: Papagiannidis, S. \& Fox, H. (2008). E-consumer behavior: past, present and future trajectories of an evolving retail revolution. International Journal of E-business Research, 4(3), 64-76.

Bulter, P. \& Peppard, J. (1998). Consumer purchasing on the internet: Processes and prospects. European Management Journal, 16(5), 600-610.

Dani, N. (2017). A study on consumer's attitude towards online shopping. International Journal of Research in Management \& Business Studies, 4(3), 42-46.

Goldsmith, R.E., \& Bridges, E. (2000). E-tailing vs. retailing: using attitudes to predict online buying behavior. Quarterly Journal of Electronic Commerce, 1(3), 254263.

Internet World Stats. (2020). Retrieved August, 2020 from World Internet Usage and population statistics: http://www.inernetlworldestats.com/stats.htm.

Kanchan, U.; Kumar, N. \& Gupta, A. (2015). A study of online purchase behavior of consumers in India. ICTACT Journal of management Studies, 1(3).

Kanupriya, D.R. \& Kaur, A. (2016). A study of behavior of consumer towards online shopping. Orbit-Biz-Dictum, 1(1), 43-55.

Karim, R.A. (2013). Customer satisfaction in online shopping: a study into the reasons for motivations and inhibitions. IOSR Journal of Business and Management, 11(6), 13-20.

Kothari, P. P., \& Maindargi, S. S. (2016). A study on customers attitude towards online 
shopping in India and its impact: with special reference to Solapur City. International Journal of Advance Research, Ideas and Innovations in Technology, 2(6), 1-10.

Schiffman, L.G. \& Kanuk, L.L. (1991). Consumer Behaviour. Fourth Edition. London. Prentice Hall International.

Sultan, M.U., Uddin, M.N. (2011).Consumers' attitude towards online shopping: factors influencing Gotland consumers to shop online. Thesis submitted to Gotland University.

Yu, T. \& Wu, G. (2007). Determinants of internet shopping behavior: An application of reasoned behavior theory. International Journal of Management, 24(4), 744762.

\section{Appendix I}

\section{Appendices}

\section{Questionnaire}

\section{Part A}

1. Name (Optional):

2. Address: (Optical):

Note: - Please tick the suitable answer.

3 . What is your gender?
(a) Male
(b) Female

4. What is your age?
(a) $16-25$ years
(b) 26-35 years
(c) 36-45 years
(d) above 45 years

5. What is your current occupation?
(a) Students
(b) Professionals
(c) Service
(d) Businessman

(e) Others

6. What is your current monthly income?
(a) Below Rs 15,000
(b) Rs 15,000 - Rs 25,000
(c) Rs 25,000 - Rs35, 000
(d) Above Rs 35,000

7. What is your degree of education currently?
(a) Secondary
(b) Bachelor
(c) Master and above

8. How much time do you spend on internet every day?
(a) Less than 2 hours
(b) 2-4 hours
(c) 4-6 hours
(d) More than 6 hours

\section{Part B}


9. What is the main reason to shop online?
(a) Easy to purchase
(b) Time Saving
(c) Variety at one shop
(d) Price
(e) Avoids hassles in shopping in store
$\square$ (e) other reason

Note: Respondents are requested to answer the following questions with answers from strongly disagree to strongly agree on a 5 point Likert Scale.

10. I get on time delivery by shopping online.
(a) Strongly Disagree
(b) Disagree
(c) Neutral/ Uncertain
(d) Agree

(a) Strongly Agree

11. Detail information is available while shopping online.
(a) Strongly Disagree
(b) Disagree
(c) Neutral/ Uncertain
(d) Agree

(a) Strongly Agree

12. I can buy the products anytime 24 hours a day while shopping online.
(a) Strongly Disagree
(b) Disagree
(c) Neutral/ Uncertain
(d) Agree

(a) Strongly Agree

13. It is easy to choose and make comparison with other products while shopping online.
(a) Strongly Disagree
(b) Disagree
(c) Neutral/ Uncertain
(d) Agree

(a) Strongly Agree

14. The website design helps me in searching the products easily.
(a) Strongly Disagree
(b) Disagree
(c) Neutral/ Uncertain
(d) Agree

(a) Strongly Agree

15. While shopping online, I prefer to purchase from a website that provides safety and ease of navigation and order.
(a) Strongly Disagree
(b) Disagree
(c) Neutral/ Uncertain
(d) Agree

(a) Strongly Agree

16. The website layout helps me in searching and selecting the right product while shopping online.
(a) Strongly Disagree
(b) Disagree
(c) Neutral/ Uncertain
(d) Agree

(a) Strongly Agree 
17. I believe that familiarity with the website before making actual purchase reduce the risk of shopping online.
(a) Strongly Disagree
(b) Disagree
(c) Neutral/ Uncertain
(d) Agree

(a) Strongly Agree

18. I prefer to buy from website that provides me with quality of information.
(a) Strongly Disagree
(b) Disagree
(c) Neutral/ Uncertain
(d) Agree
(a) Strongly Agree

19. Online shopping takes less time to purchase.
(c) Neutral/ Uncertain
(d) Agree

(b) Disagree

(a) Strongly Agree

20. Online shopping doesn't waste time.
(a) Strongly Disagree
(b) Disagree
(d) Agree

(c) Neutral/ Uncertain

(a) Strongly Agree

21. I feel that it takes less time in evaluating and selecting a product while shopping online.
(a) Strongly Disagree
(b) Disagree
(c) Neutral/ Uncertain
(d) Agree

(a) Strongly Agree

22. I feel safe and secure while shopping online.
(a) Strongly Disagree
(b) Disagree
(d) Agree

(c) Neutral/ Uncertain

(a) Strongly Agree

23. Online Shopping protects my security.
(a) Strongly Disagree
(b) Disagree

(c) Neutral/ Uncertain

(d) Agree

(a) Strongly Agree

24. I like to shop online from a trustworthy website.
(c) Neutral/ Uncertain
(d) Agree

(b) Disagree

(a) Strongly Agree

\section{Appendix II}

Frequency of Respondents' Agreement with Statements 


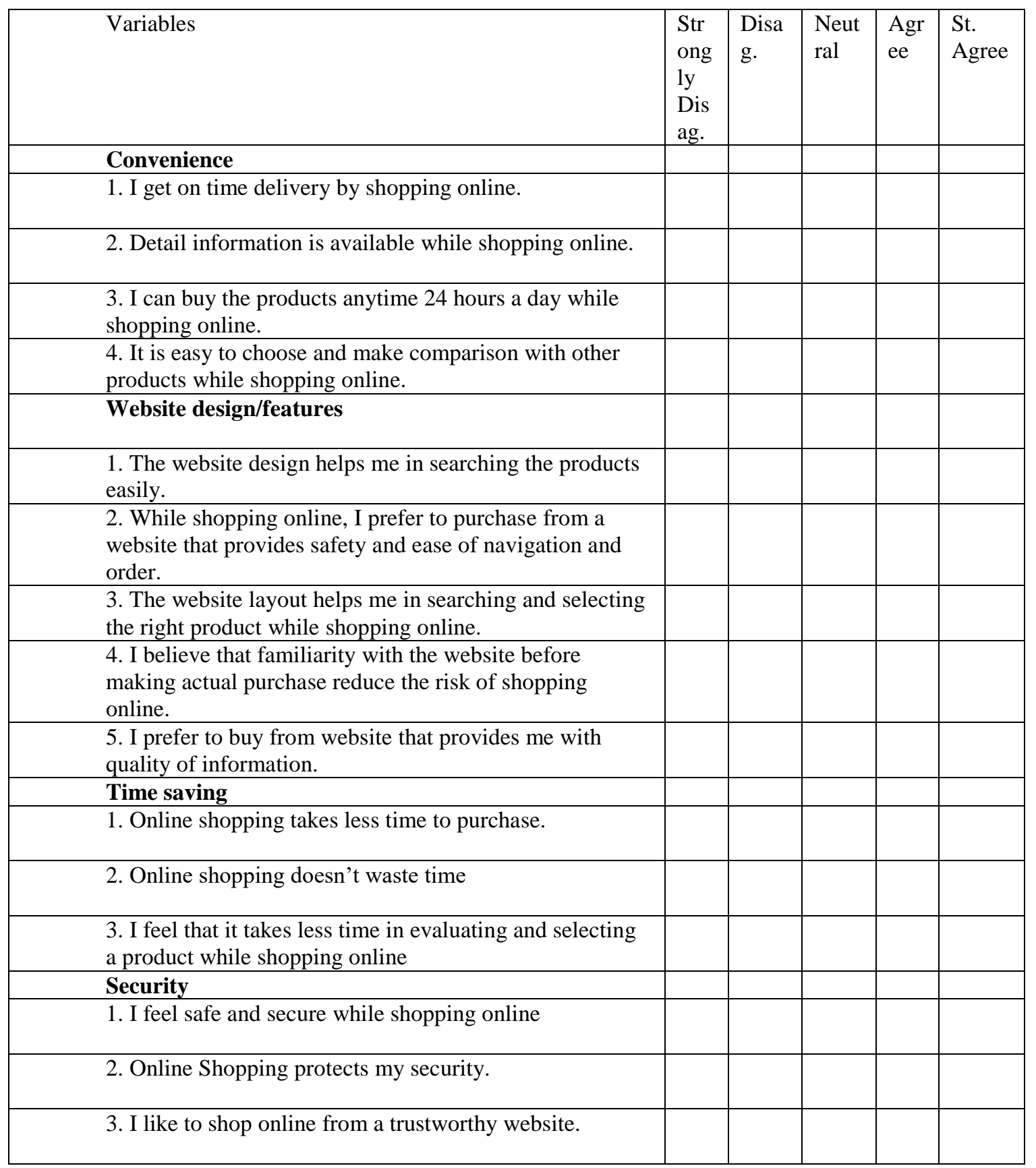

